\title{
The Impact of Tax Knowledge, Tax Morale, Tax Volunteer on Tax Compliance
}

\author{
Nyoman Sentosa Hardika*, Ketut Arya Bayu Wicaksana, I Nyoman Subratha \\ Accounting Department \\ State Polytechnic of Bali \\ Badung, Indonesia \\ *sentosahardika@pnb.ac.id, aryabayuwicaksana@pnb.ac.id, nyomansubratha@pnb.ac.id
}

\begin{abstract}
This study analyzes tax knowledge, tax morality, tax volunteers as well as tax compliance with the aim of measuring the influence of tax knowledge, tax moral and tax volunteers against tax compliance. The role of tax volunteers is important in tax understanding to increase tax compliance. Using the Slovin formula, the number of samples were taken as much as 100 samples of the total population in which there are 63,099 individual taxpayers. A Likert scale of 1 (strongly disagree) to 5 (strongly agree) was used as the study questionnaire. The test was conducted by using Partial Least Square (Smart PLS). This study showed that taxpayer compliance was significantly affected by tax knowledge, tax moral and tax volunteers. Given the importance of tax volunteer factors in increasing tax understanding and tax compliance, so the role of tax volunteers is indispensable. Tax moral is also an important factor that improves tax compliance. These meaningful results are really helpful in order to understand more about the challenges of taxpayer compliance improvement. These results also provide advanced stuffy on different tax subjects, in addition to the theoretical and social relevance, as well as the fact that study related to moral and tax volunteers is still very little.
\end{abstract}

Keywords-tax knowledge, tax moral, tax volunteer, tax compliance

\section{INTRODUCTION}

Taxes plays an important role in the national economy. Therefore, it is necessary to raise citizen awareness about the importance of tax understanding. By increasing the tax awareness, taxpayer compliance is expected to be increased. The voluntary compliance of taxpayers (voluntary compliance) is crucial in the taxation system. Compliance has been achieved more on preventive methods through law enforcement, such as tax checks and sanctions that are based on the assumption that the taxpayer will only be obedient if there is a force $[1,2]$.

In the Self-assessment system, the Government through the Directorate General of Taxation uses more voluntary compliance approaches (voluntary compliance). The SelfAssessment System (SAS) implementation requires the taxpayers have a good understanding of taxation rules. The system requires taxpayers to calculate, pay for, and report their own taxation obligations. Responsibility is solely at the taxpayer's own discretion. If there is an error in the performance of its obligations, the taxpayer will be subject to sanctions.

Community knowledge and awareness factors are one of the causes of low public compliance to pay tax [3-6]. Another factor that also affects the lack of taxpayer compliance is the moral taxpayers $[7,8]$. To increase the taxpayer compliance, the Directorate General of Taxation (DGT) involves non-authority communities in a program called tax volunteers. The contributions of academics who care about the fate of Indonesian nation and state in collaboration with DGT gives an understanding of taxes to increase public awareness in carrying out their tax obligations. The cooperation is realized by forming a tax center that houses and ensures the tax volunteer work program runs well annually. In addition to taxpayer awareness, tax moral, trust in the government, belief in the legal system, government performance, and social and cultural norms are factors that are believed to affect taxpayer compliance as well [9]. A high tax moral is required from taxpayers to achieve a high level of tax compliance. The results of the study linking morality of taxpayers to taxpayer compliance showed a positive relationship between tax morale and tax compliance, i.e. the higher intrinsic motivation to pay taxes, the higher the tax compliance [10-13].

Based on the description in the background, the main problem is how the influence of tax knowledge, taxpayers moral and the tax volunteers against taxpayer compliance.

- There is a significant influence between the understanding of taxpayers with the level of tax compliance. The better the taxpayer's understanding of taxation, the higher the level of taxpayer compliance. Taxpayer compliance in carrying out their tax obligations is affected by the level of education and understanding of taxpayers about the tax itself.

- There is a moral influence of taxpayers on taxpayer compliance. The moral reasoning theory can be used to explain the moral influence of taxpayers on taxpayers compliance. 
- There is an influence of tax volunteers on taxpayer compliance. There is a role in tax volunteers in increasing taxpayer understanding of taxpayer compliance.

\section{LITERATURE REVIEW}

\section{A. Tax Volunteers, Tax Knowledge and Taxation Awareness}

Tax volunteer is a community in which studying tax and mentoring tax reporting to taxpayers. VITA (Volunteer Income Tax Assistance) and TCE (Tax Counseling for the Elderly) are volunteers who are tasked to assist people in fulfilling their exposure rights and obligations, especially the filing of annual tax report via E-filing [14]. Gary Iskowitz of California State University Northridge has introduced VITA and TCE since 1971. In Canada the community is known as the Community Volunteer Income Tax Program (CVITP) which provides wider service activities even to tax returns for eligible taxpayers [15].

The role of tax volunteer is important to increase taxpayer compliance. Tax volunteers can take one of the roles of assistance given: The Tax Preparer, the Quality Reviewer, and the Tax Coach. As a tax preparer, tax volunteers have to obtain counting training and tax reporting, including the use of electronic filing software, as well as preparing restitution/refund of excess tax payments. The tax volunteers must have experience as a tax preparer to become quality reviewer. As quality reviewer, tax volunteers must have a tax consultant certificate. As a tax coach, tax volunteers assist with tax payment mentoring, tax reporting and tax returns including those which related to tax law issues. A tax coach must have a taxpayer certificate.

Another important factor that affects taxpayer compliance is tax knowledge. Tax knowledge can lead to unbelief and negative attitudes toward tax. While good tax knowledge is positively correlated with taxpayer attitudes and taxpayer compliance [6]. Eriksen and Fallan stated that when the level of knowledge of the tax increases, the rate of decline of tax evasion and tax compliance levels to be much higher [16].

Tax justice also affects tax compliance. Hofmann, et al stated that justice relates to the perception of justice for tax paid and compensation received by the public for the tax payable, and the perceived fairness of the procedure formulated, as well as the consequences of violations of the tax rules [9]. In connection with the taxpayer's conduct, Wenzel stated that included in tax justice were: distributive justice, procedural justice and retributive justice $[16,17]$.

Tax knowledge is an important element in the tax system with a self-assessment, especially in determining the amount of tax obligations accurately [18]. Without sufficient tax knowledge, there is a tendency for taxpayers not to obey the taxation legislation either intentionally or unintentionally. Small business taxpayers are even less likely to be aware of the lack of their tax knowledge and this become one of the causes of accidental disobedient behavior. Fallan who confirms the results of the study Schisler. Tax knowledge can significantly change attitudes towards the justice of the taxation system [18].

Tax knowledge and taxpayer awareness will affect taxpayer's attitudes and obligations. The lack of understanding of taxation regulations and how the implementation of these regulations will affect taxpayer's compliance [19]. The higher the taxpayer's knowledge and awareness on the tax regulation, the higher the taxpayer's value of compliance [20-23]. Another factors that can affect tax knowledge and compliance behaviour are the level of education, the exposure to tax education, the knowledge of e-filing and the Complexity of tax law $[6,23]$. The understanding of e-filing and the complexity of tax law will affect taxpayer's behaviour.

\section{B. Tax Moral}

The tax moral concept was introduced for the first time in 1960, s but still little attention was given by tax researchers for decades. Starting in 1990, tax moral has attracted more attention and has become a central issue in empirical study on compliance.

Tax moral is very important and integral attitude that impacts on tax compliance. Tax moral is defined as intrinsic motivation to pay tax $[7,10,12]$. Luther and Singhal define tax moral as the totality of non-monetary motivation and factors for tax compliance that is beyond the maximization of expected utilities [24]. The relationship between education and tax moral has been discussed by Torgler. He expect that education affects the tax compliance behavior of the more highly educated citizens because they may have a better aware of welfare state benefits and government wastes [25]

Kornhauser develop the theory and concept of tax moral. This concept considers tax moral research in three key areas: cognitive and affective processes (e.g. Kahan and Braman, Cullis et al., Hansen), social norms and personal values/norms (e.g. Kolstad,; Fehr and Fischbacher,; Mazar and Ariely,) and demographic factors (e.g. McGee and Tyler,; Togler; Hasseldine and Hite,) [7,12]. Personal nature is also important in shaping the individual tax morals that affect tax compliance behaviour. Previous studies show that there are individuals, who are referred as "honest taxpayers", who do not try to dodge because they are only "inclined not to avoid" [26]. On the other hand, "tax evasion" in general, has low tax moral and acts as a rational individual comparing the benefits of avoiding tax with benefits of compliance. In addition, there are individuals who can enjoy avoiding taxes and consider this as a game [24]. These studies emphasize more on relevance in understanding the level of obedience that should be met. A high tax moral is required from taxpayers to be able to achieve a high level of tax compliance. Some studies have shown that there are moral influences of taxpayers to taxpayer compliance [10,12,13,27]. High moral levels will affect taxpayers' compliance. Taxpayers who have a high moral level tend to be more obedient than taxpayers who are at a low moral level. Tax moral is also associated with domestic tax evasion. A low tax moral will result in domestic tax evasion [28]. 


\section{The Taxpayer's Compliance}

The taxpayer's compliance is defined as entering and reporting the required information in time, filling in the correct amount of the tax payable, and paying the tax in time, without any act of compulsion [29]. Disobedience arise if one of the conditions of definition is not met. Taxpayer compliance can be divided into two, namely voluntary compliance and direct enforcement. Voluntary tax compliance is key to the success of the taxation system. Taxpayers are responsible in establishing their own tax obligations and then paying and reporting tax in time. There are two kinds of adherence to: 1) Material compliance, a situation where the substantive taxpayer/essence meets all material taxation provisions, namely according to the content and the legal souls of the tax. 2) Formal compliance, A situation where taxpayers carry out tax obligations formally in accordance with the provisions of taxation law [30].

A tax system with Self-Assessment System, emphasis on the importance of voluntary compliance. The theory of tax compliance is mostly referred to behavioral theories. One theory of behaviour used was Theory of Reasoned Action $[29,31]$.

In the case of unbelief in the tax authorities, high authority power is required to enforce tax compliance and increase fines as well as the possibility of auditing may be an effective tax policy. However, in conditions where taxpayers trust government authorities, other variables become important [32]. Knowledge, attitude, moral appeal, justice and democracy can lead to voluntary obedience. High fines and checks made against taxpayers may affect taxpayer compliance and will undermine the moral of the taxpayer. Such influence would inadvertently undermine the moral taxpayers [33].

The taxpayer's compliance behaviour can be classified into four groups depicted in the form of a pyramid of compliance models adopting a series of values, beliefs, and attitudes that can be described as motivational posture. This motivation posture has two generally disobedient behaviors and two obedient behaviors that characterize the individual ways of dealing with the Revenue authority and its managed tax system $[34,35]$.

The OECD states that the more the pyramids move upward, the taxpayer's number of the compliance behaviour is less. In contrast, the cost of tax compliance will be decreased as the pressure to be obedient when the pyramid moves downwards. Implicitly, the taxpayer's compliance has a connection to the pressure and cost of tax compliance paid to reach a particular level of compliance.

\section{RESEARCH METHODS}

The purpose of this study is to understand the influence of taxation knowledge, moral taxpayers and tax volunteers against taxpayer compliance in carrying out their tax obligations.

This is an explanatory to study the relationship between variables. The data used in this study is primary data that is obtained through the questionnaire. The total tax-payer population registered in KPP Pratama Badung Selatan in 2018 is 63,099. The sample count is determined its using the Slovin formula and its obtained 100 samples. Variable measurements using Likert scale, from 1 (strongly disagree) to 5 (strongly agree). Taxpayer compliance (Y) as dependent variable, Tax Knowledge (X1) as an independent variable, Tax Moral (X2) as an independent variable and Tax Volunteer (X3) as an intervening variable. Data analysis was conducted by using Partial Least Square. Quantitative data analysis is also supported with descriptive analysis to collaborate the analysis results, so that a valid conclusion is obtained.

\section{Research Hypothesis:}

H1: Taxpayer knowledge on taxation regulations affects taxpayer compliance.

\section{H2: Tax moral affects taxpayer compliance.}

H3: Tax volunteers affects tax compliance.

H4: Taxpayer knowledge affects tax compliance through tax volunteers.

\section{RESULTS AND DISCUSSION}

\section{A. Research Variables Description}

The taxpayer understands well about the functioning of the tax as one of the state Revenue Sources (X1.6) with mean value of 4.280. Taxpayers realize that tax function as a state income source to finance development. But taxpayers are less likely to be able to self-calculate their tax obligations (X1.2) with mean value of 3.880. This indicates that not all taxpayers self-calculate their exposure obligations. X 1.2. Gets the lowest mean value compared to the other items, but still resides in very good categories.

In relation to tax moral, taxpayers will report a full major income including any other small income in his tax report form (X 2.2) but not fully report revenue from investments (X 2.4). The value of X 2.2 indicates the highest mean value of 4.280 and the X 2.4 represents the lowest mean value of 3.980 .

Taxpayers are greatly assisted by the tax volunteers who assist in the online annual tax reporting (X 3.4) with the highest mean value of 4.550 and the taxpayer is greatly assisted by the tax volunteers who help explain the rights and liabilities of his $\operatorname{tax}$ (X 3.1) with the lowest mean value of 4.190.

Taxpayers have awareness of registering as taxpayers to obtain a NPWP (Y 2.1) with the highest mean value of 4.310 . However, in case of calculating a tax owed, taxpayers are not always able to calculate correctly (Y 2.4) with mean value of 4.100. This indicates that sometimes an error occurs when the taxpayer calculates the outstanding tax. (Y 2.4) gets the lowest mean value compared to other items, but still remains in the high category. 


\section{B. Evaluation of the Measurement Model (Outer Model)}

Convergent validity, linear validity and reliability tests showed the results as required. Convergent validity shows loading factor above 0.50 , linear validity declare valid results and Cronbach's alpha and composite reliability delivers reliable results.

\section{Evaluation of Structural Model (Inner Model)}

Values R-Squares 0.75 (strong), 0.50 (moderate), and 0.25 (weak). The higher the $\mathrm{R} 2$ value, the better the predictive model of the proposed research model. Based on these results, it can be concluded that the tax knowledge (X1), taxpayer moral (X2) and tax Volunteers (X3) has an influence of $63.9 \%$ or it can be called strong enough.

\section{Hypothesis Test}

The significant rate used is $5 \%$ with a T-statistic value of 1.96. The T-Statistic value $>1.96$ indicates that the hypothesis was accepted, whereas if the T-statistic value of $<1.96$ indicates the hypothesis was rejected. The results of the hypothesis testing on this study were a direct influence, indirect influence and total impact, as follows: a) Direct influence of results shows that moral tax (X2) and tax Volunteers (X3) have a direct positive and significant influence on their tax compliance of 0.433 and 0.380 respectively, tax knowledge (X1) against tax volunteer (X2) has a positive and significant direct influence of 0.873 , while tax knowledge (X1) against tax compliance $(\mathrm{Y})$ has an insignificant positive influence of 0.032 . b) Indirect influence of tax knowledge (X1) on tax compliance (Y) through tax volunteer (X3) generates a coefficient of 0.332 with a significance value of 0.006 which demonstrates the positive and significant influence of tax knowledge on tax compliance through tax volunteer. c) The Total influence of the results showed that the tax moral (X2) has a positive and significant influence on tax compliance (Y) of 0.433 , tax knowledge (X1) has a positive and significant influence on tax compliance $(\mathrm{Y})$ of 0.364 , tax knowledge (X1) has a positive and significant influence of 0.873 on tax volunteers (X3), as well as tax volunteers (X3) has a significant positive influence of 0.380 on tax compliance (Y).

\section{E. Discussion of Research Results}

In this discussion, the study was conducted to answer the problems proposed and subsequently based on the results of the significance test will be able to answer whether the proposed hypothesis was accepted or rejected in accordance with existing data support and theoretical studies. What the results mean and why it happened will be more discussed later, as well as how its relevance to the theories and previous studies.

Based on the estimate of structural model parameters obtained tax knowledge line coefficient value significant effect on taxpayer compliance of 0.364 . These results answered the number one research hypothesis. The results of this study are in line with previous studies by Newman and Nokhu [6] and Eriksen \& Fallan [16]. These results are also in line with previous studies stating that the higher the knowledge and awareness of tax laws, the higher the taxpayer's value of compliance [20-22]. Tax knowledge is an important factor in determining the amount of tax obligations accurately in the tax system with the self Assessment [18]. The understanding of efiling and the complexity of tax law also affects the behavior of tax compliance. The level of education, tax understanding, is also another factor that affects tax compliance [6,23]. Results from the study found that tax knowledge has significant effect on tax compliance. This is related to the understanding of taxpayers on taxation regulations and understanding of e-filing as a means of tax reporting.

The results showed that tax moral significantly affects the taxpayer's compliance with a coefficient value of 0.433 . These results were in line with Luttmer's \& Singhal Findings, Kemme, Parikh, \& Steigner, Cummings, Martinez-Vazquez, McKee, \& Torgler [13]. The personal nature that constitutes the individual's moral taxpayers will affect tax compliance. Honest taxpayers will not try to dodge, whereas taxpayers who have a low tax moral would tend to dodge tax payments. This corresponds to the Theory of moral reasoning [36]. The results of this study showed that taxpayers have good moral (honest) so tend to be obedient to pay taxes. Good moral is believed to be in correlation with high religious level of society. Employee taxpayers are more compliant than entrepreneurs ' taxpayers. This is due to the income the taxpayer has obtained the employees of the job is already done cutting by the employer so there is no gap to avoid tax payments.

The results showed that tax volunteers had a significant influence on the taxpayer's compliance of 0.380 . The importance of a tax volunteer role in increasing taxpayer compliance is as a tax preparer. The role of the tax preparer is to assist taxpayers in calculating the amount of tax owed, report the annual tax report by e-filing or e-form. This is in line with one of the roles of volunteer taxes in the United States (VITA) that tax volunteers help people fulfill their tax rights and obligations especially for the annual tax report charging assistance via e-Filing [14].

The results showed that tax knowledge has significant effect on tax compliance through tax volunteers of 0.332 . In the case of a tax community that lacks of knowledge about tax, the role of tax volunteers will be very helpful in increasing taxpayer's compliance. Tax volunteers increase the influence of tax knowledge on taxpayer's compliance. The existence of tax volunteers can assist in calculating taxes, preparing tax payments and annual tax reporting. The role of tax volunteers is essential for increasing taxpayer understanding of taxation rules, so that socialization and volunteer tax activities should be done regularly. 


\section{CONCLUSION AND SUGGESTION}

\section{A. Conclusion}

Based on the study results regarding the influence of taxpayers' knowledge, the moral taxpayers and the tax volunteers against taxpayer compliance, it can be concluded:

- The results show that tax knowledge has a significant positive effect on tax compliance. It means that an increased in taxpayer knowledge will increase taxpayer compliance.

- Based on the field study and study analysis, it can be stated that the moral taxpayers have a positive and significant effect on the taxpayer's compliance. It means that a moral tax is required to comply with tax regulation, then payment compliance and tax reporting will increase.

- The results showed that the role of tax volunteers was crucial for increasing taxpayers ' compliance. Tax volunteers can increase the taxpayer's understanding in relation to tax regulation so that taxpayer compliance will also be increased.

\section{B. Suggestions}

- In the self-assessment system that gives the taxpayer confidence to register, calculate, pay and report his/her tax obligations, the knowledge of tax regulation is very important. Therefore, the role of the Directorate General of Taxation in increasing understanding is indispensable through the socialization of tax regulation. Tax volunteers can help the Directorate General of Taxation to conduct this socialization. Besides, it needs to be improved tax inclusion activities, especially in colleges.

- Trust to the government and tax authorities greatly affects the moral taxpayers. It takes a way to motivate taxpayers. One of them is in the form of socializing the optimal tax understanding to the community. This affects the public to pay tax voluntarily.

- The Directorate General of Taxation regularly and continuously must provide training to staff. Staff can communicate and provide good service to taxpayers, thereby increasing satisfaction and trust to the Directorate General of Taxation.

- It needs to be done advanced research related to other factors that affect tax compliance beyond the knowledge, moral and tax volunteers, so that tax compliance can be increased.

\section{ACKNOWLEDGMENT}

The author would like to thank the State Polytechnic of Bali for permission to use its facilities for research.

\section{REFERENCES}

[1] M.G. Allingham and A. Sandmo, "Income Tax Evasion: A Theoritical Analysis," J. Public Econ., vol. 1, pp. 323-338, 1972.

[2] R.B. Whait, "Exploring innovations in tax administration: A Foucauldian perspective on the history of the Australian Taxation Office's compliance model," eJournal Tax Res., vol. 12, no. 1, pp. 130 161,2014

[3] J. Kasipillai, N. Aripin, and N.A. Amran, "The Influence of Education on Tax Avoidance and Tax Evasion," eJournal Tax Res., vol. 1, no. January, pp. 134-146, 2003.

[4] N. Hassan, A. Nawawi, and A.S.A.P. Salin, "Improving Tax Compliance via Tax Education - Malaysian Experience," malaysian Account. Rev., vol. 15 (2), no. December 2016, pp. 243-262, 2016.

[5] C.O. Olaoye, A.R. Ayeni-agbaje, and A.P. Alaran-ajewole, "Tax Information , Administration and Knowledge on Tax Payers Compliance of Block Moulding Firms in Ekiti State," J. Financ. Account., vol. 5, no. 4, pp. 131-138, 2017.

[6] W. Newman and M. Nokhu, "Evaluating the Impact of Tax Knowledge on Tax Compliance among Small Medium Enterprises in a Developing Country," Acad. Account. Financ. Stud. J., vol. 22, no. 6, pp. 1-14, 2018.

[7] P. Alexander, M. Balavac, A. Lymer, D. Massey, P. Alexander, and E. B. Centre, Improving Tax Literacy and Tax Morale of Young Adults End of Project Report to the Chartered Institute of Taxation.

[8] J. Stead and R. Orozco, "What is Driving Tax Morale? An empirical analysis on social taxation," 2019.

[9] E. Hofmann, E. Hoelzl, and E. Kirchler, "Europe PMC Funders Group Preconditions of Voluntary Tax Compliance: Knowledge and Evaluation of Taxation , Norms , Fairness , and Motivation to Cooperate," Z Psychol., vol. 216, no. 4, pp. 209-217, 2012.

[10] E. Igbeng, A. Tapang, and O. Usang, "Analysis of tax morale and tax compliance in Nigeria," Covenant University, 2012.

[11] D. Purnamasari and Y. Sudaryo, "The Effect of Knowledge Taxpayer Moral Taypayer and Tax Sanctions on Taxpayers Compulsory,” Int. J. Trade, Econ. Financ., vol. 9, no. 5, pp. 214-219, 2018.

[12] I.A. Horodnic, "Tax morale and institutional theory: a systematic review," Int. J. Sociol. Soc. Policy, vol. 38, no. 9-10, pp. 868-886, 2018.

[13] A.L. Martinez and M.L.B. Coelho, "Tax Morals and the Brazilian Citizen: Empirical Study,” SSRN Electron. J., pp. 607-622, 2019.

[14] P.J. Davis-smith, R.P. Thomas, and D.C. Cico, "Examining Motivations To Volunteer with the Volunteer Income Tax Assistance ( VITA ) Program: How Motivations Influence Future Volunteer Behavior,' 1991.

[15] A. Dwianika and I.P. Sofia, "Relawan Pajak: Bagaimana Pelatihan Pajak Mempengaruhi Kepuasan Wajib Pajak Pada Masyarakat Urban? (Stud Pada Tax Centre Universitas Pembangunan Jaya)," Keberlanjutan, vol. 4, no. 2, p. 1176, 2019.

[16] I. Mukhlis and Y. Soesetio, "The Role of Taxation Education on Taxation Knowledge and Its Effect on Tax Fairness as well as Tax Compliance on Handicraft SMEs Sectors in Indonesia," Int. J. Financ. Res., vol. 6 (4), no. October 2016, pp. 161-169, 2015.

[17] M. Wenzel, “Tax compliance and the psychology of justice: Mapping the field," Tax. Democr. Underst. Tax Avoid. Evas., pp. 41-70, 2017

[18] N. Saad, "Fairness Perceptions and Compliance Behaviour: The Case of Salaried Taxpayers in Malaysia after Implementation of the SelfAssessment System,” eJournal Tax Res., vol. 8, no. 1, pp. 15-33, 2010.

[19] G. Mascagni and F. Santoro, "African Tax Administration Paper 1 What is the Role of Taxpayer Education in Africa?," no. April, 2018.

[20] R.M.K. Wong and A. Lo, "Can education improve tax compliance? Evidence from different forms of tax education," Hong Kong, China, 2015 . 
[21] O.M. Bernard, F.S. Memba, and O. Oluoch, "Influence of Tax Knowledge and Awareness on Tax Compliance Among Investors in the Export Processing Zones in Kenya,” Int. J. Sci. Res. Manag., vol. 06, no. 10, pp. 728-733, 2017.

[22] A. Eric, A. Solomon, and A.K. Nicholas, "An Empirical Assessment of Tax Knowledge, Socio-Economic Characteristics and Their Effects on Tax Compliance Behaviour in Sunyani Municipality , Ghana Corresponding Author: Amankwaah Eric," vol. 10, no. 4, pp. 148-153, 2019.

[23] N.L.M. Sugiartini, N.S. Hardika, and N.N. Aryaningsih, "The Effect of Taxation Understanding and Taxpayer Attitudes on Taxpayer Compliance with Implementation of E-Filing System as Mediation Variable", J. Appl. Sci. Accounting, Financ. Tax, vol. Vol. 3 No., pp. $19-29,2020$.

[24] E.F.P. Luttmer and M. Singhal, “Tax morale,” J. Econ. Perspect., vol. 28 , no. 4, pp. 149-168, 2014.

[25] D. Rodriguez-Justicia and B. Theilen, "Education and tax morale," J. Econ. Psychol., vol. 64, pp. 18-48, 2018

[26] R.G. Cummings, J. Martinez-Vazquez, M. McKee, and B. Torgler, "Tax morale affects tax compliance: Evidence from surveys and an artefactual field experiment," J. Econ. Behav. Organ., vol. 70, no. 3, pp. 447-457, 2009.

[27] C.C. Williams and B. Krasniqi, "Evaluating the individual- and countrylevel variations in tax morale: Evidence from 35 Eurasian countries," J. Econ. Stud., vol. 44, no. 5, pp. 816-832, 2017.

[28] D.M. Kemme, B. Parikh, and T. Steigner, "Tax Morale and International Tax Evasion,” J. World Bus., vol. 55, no. 3, p. 101052, 2020.
[29] N.S. Hardika, I.K. Sukayasa, and N.N. Yintayani, "The effect of administration system and tax reports on line on service quality and restaurant's tax-payer compliance in Badung Regency," 2017, pp. 134140.

[30] R. Hastuti, "Tax Awareness And Tax Education: A Perception Of Potential Taxpayers," Int. J. Business, Econ. Law, vol. 5, no. 1, p. 9, 2014.

[31] R.M. Aondo, "Effectiveness of Taxpayer Education on Tax Compliance for Small and Medium Enterprises in Kenya: A Study of Selected Business Enterprises in Kitengela Town in Kajiado County," Int. J. Manag. Entrep. Res., vol. 1, no. 3, pp. 114-123, 2019.

[32] K. Gangl, E. Hofmann, B. Hartl, and M. Berkics, "The impact of powerful authorities and trustful taxpayers: evidence for the extended slippery slope framework from Austria, Finland, and Hungary," Policy Stud., vol. 2872, 2020.

[33] E. Kirchler, S. Muehlbacher, B. Kastlunger, and I. Wahl, "Why pay taxes?: A review of tax compliance decisions," Dev. Altern. Fram. Explain. Tax Compliance, vol. 9780203851, no. December, pp. 15-31, 2010

[34] OECD, "Compliance Risk Management: Managing and Improving Tax Compliance," Oecd, no. October, pp. 1-73, 2004.

[35] O.F.O.R.E. Co-operation, C. For, and T. A. X. Policy, "FORUM ON TAX ADMINISTRATION : COMPLIANCE SUB-GROUP Information Note Managing and Improving Compliance: Recent Developments in Compliance Risk Treatments March 2009," Taxes, no. March, 2009.

[36] Y.M. Basri, A.R. Tanjung, A. Azhar, and S. Indrastuti, "Detterent Factor and Social-Psychology Factors in Voluntary Tax Compliance," 2019, vol. 2019, pp. 602-618 